Грудзевич Ю. I., grudzevychukr@gmail.com,ORCIDID:0000-0002-2790-5681,

к.е.н., дои., доиент кафедри обліку і оподаткування, Волинський наиіональний університет імені Лесі Українки, м. Луцьк

Скорук O. B., skoruklena@gmail.com,ORCID ID: 0000-0002-9497-1945, к.е.н., дои., доцент кафедри обліку і оподаткування, Волинський національний університет імені Лесі Украӥнки, м. Луиььк

\title{
ОБЛІКОВО-АНАЛІТИЧНЕ ЗАБЕЗПЕЧЕННЯ КОНСАЛТИНГУ У СФЕРІ РОЗСТРОЧЕННЯ СПЛАТИ ПОДАТКОВИХ ЗОБОВ'ЯЗАНЬ
}

\begin{abstract}
Анотація. Одним із можливих шляхів зменшення податкового тиску на діяльність суб'єктів бізнесу є дослідження можливості відстрочення сплати зобов'язань за окремими видами податків. Поряд із розробкою інструментів оптимізації податкового навантаження, вивчення иієї проблеми є актуальним, потребує детального аналізування та підготовки до реалізації. У контексті дослідження важливо визначити можливість залучення, роль та вагомість впливу фахівия з податкового консалтингу. Тому в статті першочергово подано визначення, загальну класифікацію консалтингу та окремо деталізовано види консалтингу в сфері обліку, аналізу, аудиту й оподаткування, виділено ліміт повноважень та обов'язків фахівия за цим напрямом роботи. Обтрунтовано необхідність аналізування показників діяльності підприємства та доцільність розстрочення сплати податкового зобов'язання. Розстрочення сплати податкових зобов'язань має кредитну етимологію, тому в даному контексті запропоновано розглядати фіскальний орган як потенційного кредитора, а підприємство, керівники якого прийняли рішення щзодо необхідності оптимізації податкових зобов'язань, як боржника. Подано структуру оцінювання фінансового стану в розрізі основних складових: загрози виникнення, накопичення або непогашення податкового боргу підприємства; оцінки фінансово-господарської діяльності та платоспроможності підприємства; фінансової стійкості та динаміки основних показників діяльності підприємства; оцінки забезпечення податкового кредиту. Також у статті звернено увагу на такі специифічні показники, як коефіиієнт загрози виникнення податкового боргу та коефіцієнт покриття. Обгрунтовано необхідність розрахунку планового обсягу коштів, які можуть надійти на рахунки підприємства протягом терміну розгляду заявки на розстрочення. Здійснено структурування основних етапів процесу отримання розстрочки сплати податкових зобов'язань.
\end{abstract}

Ключові слова: консалтинг, податки, податок на прибуток, податкове зобов'язання, розстрочення сплати податкового зобов'язання, відстрочення сплати податкового зобов'язання, оптимізація податкового навантаження, податковий борг.

Grudzevych Yu. I., grudzevychukr@gmail.com, ORCID ID: 0000-0002-2790-5681,

Ph.D., Associate Professor, Associate Professor of the Department of Accounting and Taxation, Lesya Ukrainka Volyn National University, Lutsk

Skoruk O. V.,

skoruklena@gmail.com, ORCID ID: 0000-0002-9497-1945,

Ph.D., Associate Professor, Associate Professor of the Department of Accounting and Taxation, Lesya Ukrainka Volyn National University, Lutsk

\section{ACCOUNTING AND ANALYTICAL PROVISION OF CONSULTING IN THE FIELD OF DEFERRED PAYMENT OF TAX LIABILITIES}

\footnotetext{
Abstract. One of the possible ways to reduce the tax pressure of business entities is the possibility of deferred payments through the involvement of specialists in tax consulting. Along with the development of tools to optimize the tax burden, the study of these problems is relevant, requires detailed analysis and preparation for implementation. During the study, the possibilities of involvement, role and importance of the influence of tax consulting specialists can be determined. Therefore, the article first of all presents the definition, general classification of consulting and details the
} 
types of consulting in the field of accounting, analysis, audit and taxation, highlights the limits of authority and responsibilities of a specialist in this area. The necessity of analyzing the indicators of the enterprise's activity and the expediency of deferring the payment of tax liability is substantiated. Deferred payment of tax liabilities has a credit etymology, so in this context it is proposed to consider the fiscal authority as a potential creditor, and the company whose managers have decided on the need to optimize tax liabilities as a debtor. The structure of assessing the financial condition in terms of the main components is given: the threat of occurrence, accumulation or non-repayment of tax debt of the enterprise; assessment of financial and economic activities and solvency of the enterprise; financial stability and dynamics of the main indicators of the enterprise; assessments of tax credit security. The article also draws attention to special indicators, such as the risk factor for tax debt and the coverage ratio. The necessity of calculation of the planned volume which can be reliable on accounts of the enterprise during term of revision of requests for installments is substantiated. The main stages of the process of obtaining installments for the payment of additional appeals have been structured.

Key words: consulting, data, profit submission, tax appeals, expansion of tax attraction payments, deferral of tax appeal payments, tax burden optimization, tax debt.

\section{JEL Classification: M41 \\ DOI: https://doi.org/10.36477/2522-1205-2021-65-15}

Постановка проблеми. Консалтинг як специфічний вид професійної діяльності займає особливе місце у розвитку сучасного бізнесу. Залучення фахівця-консультанта на певному етапі розвитку підприємства сприяє здійсненню неупередженого оцінювання, пошуку нових підходів та варіантів вирішення не лише ситуативних, а й стратегічних проблем генерування інноваційних ідей та прийняття єдиного правильного рішення. Однією 3 основних характеристик досвідченого фахівця 3 консалтингу в сфері обліку, аналізу, аудиту й оподаткування є достатність різнопланового досвіду для не лише надання відповіді на типові, часті запити керівників підприємства, а й допомоги у вирішенні специфічних проблем, таких як розстрочення сплати податкових зобов'язань, що в багатьох дослідженнях розглядається як один із шляхів зниження податкового навантаження.

Аналіз останніх досліджень і публікацій. I. Р. Безпалько на прикладі Німеччини визначає основну роль інституції податкового консультування. В. С. Рейкін систематизує основні тенденції розвитку консалтингу в Україні. О. Г. Кідріна розглядає розстрочення сплати податкових зобов'язань саме як один із напрямів оптимізації податкового навантаження на підприємство. Проте можливість участі консультанта в процесі отримання розстрочки платежу тематикою статті не передбачено.

Постановка завдання. Основне завдання даного дослідження автори вбачають у необхідності структурування процесу розстрочення сплати податкових зобов'язань та участі консультанта в якісній його реалізації.

Виклад основного матеріалу дослідження. На сьогодні поняття “консалтинг” у науковій сфері визначають як вид інтелектуальної діяльності, основним призначенням якої $є$ аналізування фактичних показників, обгрунтування запропонованих перспектив розвитку тієї чи іншої сфери діяльності суб'єкта бізнесу, та за необхідності контролю їі реалізації. Спектр послуг, які можуть надавати фахівці $з$ консалтингу, широкий, якщо йдеться про всі сфери діяльності підприємства, а саме: консалтинг у сфері загального управління підприємством, маркетинговий консалтинг, юридичний консалтинг, IT-консалтинг, виробнича й технологічна сфери діяльності. Досвідчені фахівці-обліковці можуть надавати послуги кадрового, фінансового й податкового консалтингу $[3,5]$. У контексті наукового дослідження слід ширше трактувати поняття податкового консалтингу. В цій сфері консультування фахівці можуть як надавати власне дорадчі послуги, так і вести бухгалтерський і податковий облік, складати звітність та нести відповідальність за якість та повноту наданих послуг. Важливою умовою якісного податкового консультування $\epsilon$ не лише надання послуги в умовах завершеного податкового періоду, а й робота “на випередження”, тобто уникнення помилок у діяльності, виникнення фіскальних переплат чи недоплат. Класифікацію консалтингових послуг узагальнено на рисунку 1.

Оптимізація податкового навантаження може здійснюватися за кількома напрямами. Одним із них є поділ підприємства, господарська діяльність якого в грошовому вираженні не відповідає ліміту підприємства-“спрощенця” або перебуває на загальній системі оподаткування на дрібніші одиниці. Цікавим є варіант із оптимізації співпраці з контрагентами, в межах якого надають перевагу однорідним правовідносинам. Дещо специфічним варіантом оптимізації розмірів податкового навантаження є мінімізація або відмова від певних операцій, що є об'єктом оподаткування без шкоди для господарської діяльності підприємства. Такий напрям оптимізації [4] потребує комплексного підходу і прийняття управлінських рішень спільно 3 фахівцями, що розвивають основну діяльність суб'єкта господарювання. Достатньо розповсюдженим напрямом оптимізації податкового навантаження є зміна реєстрації підприємства у регіоні, де існують податкові пільги або можливість використання пільги та преференції, які надані окремим сферам бізнесу. 


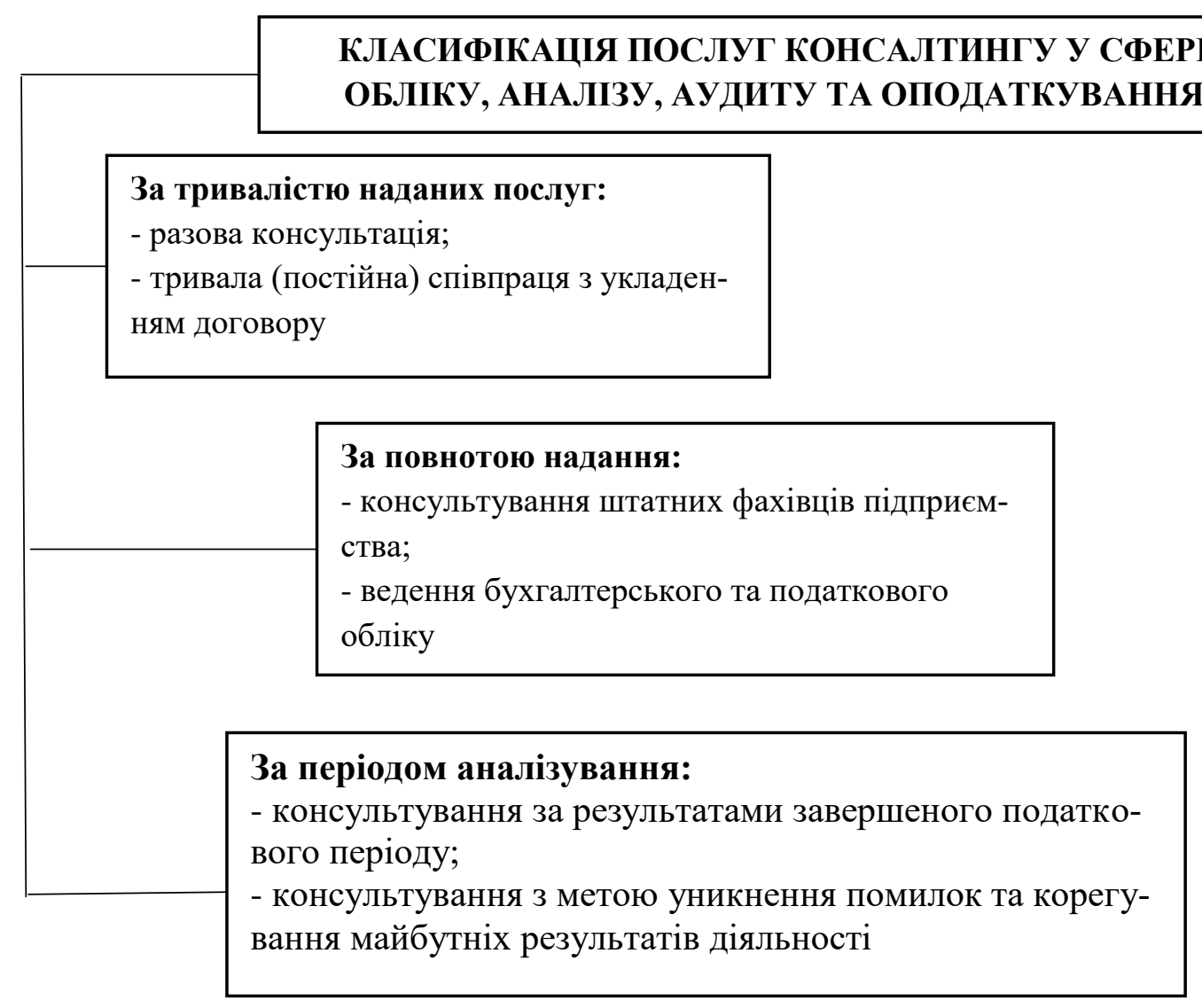

Рис. 1. Класифікація послуг консалтингу в сфері обліку, аналізу, аудиту та оподаткування Джерело: узагальнено авторами

Об'єктом наукового дослідження у статті є розстрочення платежів до бюджету. Консультування у сфері розстрочення податкових зобов'язань, що фактично виникли за результатами річного декларування, можна класифікувати як разову послугу 3 метою допомоги фахівцям підприємства. Основним завданням $є$ отримання від органу фіскального нагляду дозволу на сплату повної суми податку рівними частинами, що, своєю чергою, знизить вірогідність виникнення розриву в операційних коштах підприємства.

Нормативні акти за даною тематикою $[1,2]$ розрізняють два суміжні поняття - розстрочення та відстрочення сплати податків. Розстрочення розглядають як надання платнику податків бюджетного кредиту для наступного погашення основної суми та відсотків рівними частками. Відстрочення передбачає перенесення сплати основної суми боргу з умовою сплати рівними частками лише відсотків. Основним завданням фахівцяконсультанта за вказаною проблематикою є забезпечення якісного аналізування фінансового стану для підтвердження платоспроможності підприємства. Підставою для розстрочення грошових зобов'язань підприємств і надання їм достатніх доказів $€$ існування обставин, що свідчать про наявність загрози виникнення або накопичення податкового боргу підприємства.
Розстрочення сплати податкових зобов'язань має кредитну етимологію, тому в цьому контексті варто розглядати фіскальний орган як потенційного кредитора, а підприємство, керівники якого прийняли рішення про необхідність оптимізації податкових зобов'язань, як боржника. У зв'язку з цим аналізування фінансового стану має спільні ознаки 3 процесом обгрунтування кредитоспроможності потенційного позичальника у випадку, коли кредитором виступає інший суб'єкт.

За результатами аналізу фінансового стану визначаються такі складові оцінювання:

- загроза виникнення, накопичення або непогашення податкового боргу підприємства;

- оцінка фінансово-господарської діяльності та платоспроможності підприємства;

- фінансова стійкість та динаміка основних показників діяльності підприємства;

- оцінка забезпечення податкового кредиту.

Структуру оцінювання фінансового стану наведено в табл. 1 . 
Структура оцінювання фінансового стану підприємства для отримання розстрочення сплати податкового зобов'язання за основними складовими

\begin{tabular}{|c|c|c|}
\hline Складова оцінювання & $\begin{array}{c}\text { Коефіцієнт, що розрахо- } \\
\text { вується в межах складової }\end{array}$ & $\begin{array}{c}\text { Показники, аналіз динаміки яких } \\
\text { необхідний у межах оцінювання }\end{array}$ \\
\hline $\begin{array}{l}\text { Загроза виникнення, накопичення } \\
\text { або непогашення } \\
\text { боргу підприємства }\end{array}$ & $\begin{array}{l}\text { Коефіцієнт загрози виник- } \\
\text { нення податкового боргу }\end{array}$ & \\
\hline \multirow{2}{*}{$\begin{array}{l}\text { Оцінка фінансово-господарської } \\
\text { діяльності та платоспроможності } \\
\text { підприємства }\end{array}$} & Коефіцієнт покриття & $\begin{array}{l}\text { Динаміка обсягів виробництва } \\
\text { реалізації продукції підприємства }\end{array}$ \\
\hline & загальної & $\begin{array}{l}\text { Аналіз фінансових результатів (чи- } \\
\text { стий дохід, собівартість продукції, } \\
\text { валовий прибуток, чистий прибуток) }\end{array}$ \\
\hline \multirow[t]{3}{*}{$\begin{array}{l}\text { Аналіз фінансової } \\
\text { підприємства }\end{array}$} & $\begin{array}{l}\text { Наявність } \\
\text { оборотного капіталу }\end{array}$ & Оцінка капіталу \\
\hline & \multirow{2}{*}{$\begin{array}{l}\text { Загальна величина капіталу } \\
\text { для формування запасів та } \\
\text { затрат }\end{array}$} & Зміни майнового стану підприємства \\
\hline & & Характеристика основних засобів \\
\hline \multirow{3}{*}{$\begin{array}{l}\text { Оцінка забезпечення податкового } \\
\text { кредиту }\end{array}$} & & Характеристика оборотних засобів \\
\hline & & $\begin{array}{l}\text { Характеристика, розшифровка } \\
\text { дебіторської заборгованості та зо- } \\
\text { бов'язань }\end{array}$ \\
\hline & & $\begin{array}{l}\text { Основні економічні показники } \\
\text { підприємства на період дії розстроч- } \\
\text { ки }\end{array}$ \\
\hline
\end{tabular}

Джерело: узагальнено авторами на основі [2]

Відповідно до вказаної таблиці структура оцінювання фінансового стану підприємства здійснюється за основними складовими з розрахунком стандартних та специфічних коефіцієнтів. При обгрунтуванні необхідності розстрочення сплати податкового зобов'язання розраховується коефіцієнт загрози виникнення податкового боргу.

$$
\mathrm{K}_{3}=\frac{\text { Ал-Кн }}{\text { Зпб }},
$$

де Ал - високоліквідні активи, наявні у платника податків на дату наданої заявником звітності;

Зпб - загальна сума поточних грошових зобов'язань платника податків 3 усіх податків та інших обов'язкових платежів, термін сплати яких припадає на той же податковий період, що і грошове зобов'язання, яке підприємство-платник планує розстрочити;

Кн - грошові кошти, які надійдуть 3 дати наданої заявником звітності до настання граничного терміну.

На нашу думку, суть останньої складової вказаної формули розрахунку потребує додаткового роз'яснення. У цьому випадку аналізується період iз дати подання документів на розстрочку до настання граничного терміну сплати зобов'язання.

$$
\mathrm{K}_{\mathrm{H}}=\frac{\mathrm{B \Pi}}{\text { Тп }} * T \partial,
$$

де Вп - дохід від реалізації продукції, товарів, робіт і послуг у звітному періоді;

Тп - кількість днів звітного періоду;

Тд - кількість днів із дати наданої заявником звітності до настання граничного терміну сплати грошових зобов'язань.
Зазначимо, що, здійснюючи оцінювання за окресленим напрямом, обов'язково маємо аналізувати динаміку певних груп показників, що й забезпечить повноту дослідження та доведе достовірність поданої інформації, підтвердженої фінансовою звітністю підприємства. Наприклад, у структурі оцінки фінансово-господарської діяльності та платоспроможності підприємства передбачено аналіз динаміки обсягів виробництва та реалізації продукції підприємства. Вихідну інформацію для розрахунку таких показників можна отримати зі статистичної звітності підприємства та форми № 2. Вказану форму звітності використовують для розрахунку динаміки чистого доходу, собівартості реалізованої продукції, товарів, робіт і послуг, валового та чистого прибутку.

Отже, процес отримання розстрочки сплати податкових зобов'язань можна структурувати у такі етапи:

- попередній етап - формування розміру податкового зобов'язання та виникнення необхідності розстрочення;

- етап аналізування - розрахунок показників оцінювання фінансового стану підприємства для отримання розстрочення сплати податкового зобов'язання;

- завершальний етап - отримання погодження контролюючого органу, визначення основних сум та граничних термінів сплати розстроченого податкового зобов'язання.

Висновки i перспективи подальших досліджень у даному напрямі. Консультаційні послуги у сфері обліково-аналітичного забезпечення 
розстрочення податкових зобов'язань $є$, як зазначалося вище, поточною проблемою в діяльності підприємства. Поряд із вирішенням такого завдання, слід приділити увагу пошуку конкретних інструментів оптимізації розміру податкового зобов'язання, які можна реалізувати в поточному періоді. Тому перспективи подальших досліджень вбачаємо в розробці як універсальних, так і специфічних рекомендацій керівникам, які можна застосувати в поточному році щодо оптимізації податкового навантаження, яке треба сплатити в наступних періодах.

\section{ЛIТЕРАТУРА}

1. Податковий кодекс України від 2 груд. 2010 р. № 2755-VI. URL: https://zakon.rada.gov.ua/ laws/show/2755-17\#Text.

2. Порядок розстрочення (відстрочення) податкових зобов'язань (податкового боргу) платників податків, затв. Наказом Міністерства доходів і зборів України від 10 жовт. 2013 р. № 574. URL: https://zakon.rada. gov.ua/laws/show/z1853-13\#Text.

3. Безпалько I. Р. Податкове консультування в Німеччині: досвід для України. Ефективна економіка. 2018. № 4. URL: http://www.economy. nayka.com.ua/pdf/4_2018/47.pdf.

4. Кідріна О. Г., Фролова А. В. Оптимізація податкового навантаження на макро- та мікрорівні. Вісник економіки транспорту i промисловості. 2018. № 64. С. 135-141.
5. Рейкін В. С., Макара О. В. Консалтинг в Україні: оцінка стану та тенденції розвитку. Інфраструктура ринку. 2020. № 39. С. 97-101.

\section{REFERENCES}

1. Podatkovyj kodeks Ukrainy vid 2 hrud. $2010 \mathrm{r}$. № 2755-VI, available at: https://zakon.rada.gov.ua/ laws/show/2755-17\#Text.

2. Poriadok rozstrochennia (vidstrochennia) podatkovykh zobov'iazan' (podatkovoho borhu) platnykiv podatkiv, zatv. Nakazom Ministerstva dokhodiv i zboriv Ukrainy vid 10 zhovt. 2013 r. № 574, available at: https://zakon.rada. gov.ua/laws/show/z185313\#Text.

3. Bezpal'ko, I. R. (2018), Podatkove konsul'tuvannia v Nimechchyni: dosvid dlia Ukrainy, Efektyvna ekonomika, № 4, available at: http://www.economy. nayka.com.ua/pdf/4_2018/47.pdf.

4. Kidrina, O. $\bar{H}$. and Frolova, A. V. (2018), Optymizatsiia podatkovoho navantazhennia na makro- ta mikrorivni, Visnyk ekonomiky transportu i promyslovosti, № 64, s. 135-141.

5. Rejkin, V. S. and Makara, O. V. (2020), Konsaltynh v Ukraini: otsinka stanu ta tendentsii rozvytku, Infrastruktura rynku, № 39, s. 97-101.

Стаття надійила до редакиіï 23 листопада 2021 року 